\author{
Elżbieta HOROSZEWICZ \\ Edyta SWEKLEJ ${ }^{2}$ \\ Roman NIEDZIÓŁKA ${ }^{3}$ \\ Krzysztof TERESZKIEWICZ ${ }^{4}$
}

\title{
WYKORZYSTANIE PSÓW JAKO FORMA WZBOGACENIA OFERTY GOSPODARSTW AGROTURYSTYCZNYCH
}

\begin{abstract}
Agroturystyka jest coraz częściej docenianą formą spędzania wolnego czasu, na co wskazuje wzrost liczby gospodarstw agroturystycznych. Zmiana trendu wypoczynku z pasywnego na aktywny, której przykładem mogą być psie zaprzęgi. Dobrym przykładem umiejętnego połączenia edukacji kulturowej i aktywnego wypoczynku również z udziałem psów jest questing. W Polsce intensywnie przybywa szlaków questingowych, a ich liczba przekracza 250. W badaniach oceniano oferty aktywnych form spędzania wolnego czasu w gospodarstwach agroturystycznych w aspekcie jej wzbogacenia poprzez możliwość wypoczynku z psem. Niniejsza praca powstała na podstawie ankiet przeprowadzonych wśród właścicieli gospodarstw agroturystycznych z terenu całej Polski. Ponadto w badaniu udział brały osoby zainteresowane aktywnym spędzaniem wolnego czasu na wsi lub na łonie natury. Dla tych turystów najbardziej aktywną formą spędzania czasu były spacery i ognisko, a w okresie zimowym kulig. Natomiast forma spędzania wolnego czasu z udziałem psich zaprzęgów stanowiła $60 \%$. Na uwagę zasługuje z jednej strony fakt posiadania psów przez turystów (59\%) i chęć zabrania go na urlop (51\%). Jednocześnie najbardziej powszechną ofertą gospodarstw agroturystycznych był dostęp do boiska (69\%), a psie zaprzęgi występowały tylko w $2,5 \%$. Wśród oferty psich zaprzęgów najliczniej występowały treningi z psami zaprzęgowymi, czy nauka poszczególnych komend i pracy na wózku czy saniach. Natomiast pokazy zachowań psów w warunkach ekstremalnych należały do najmniej licznych ofert, dlatego że gospodarstwo często było zmuszone korzystać z usług wykwalifikowanych firm. Jednak dużym zainteresowaniem cieszyła się odpłatna forma szkolenia psów pod okiem trenera oraz nauka komend i instruktażu zachowania z psem w różnych sytuacjach. Pokazały one, że profesjonalnie
\end{abstract}

1 Dr inż. Elżbieta Horoszewicz, Instytut Bioinżynierii i Hodowli Zwierząt, Uniwersytet Przyrodniczo-Humanistyczny w Siedlcach, ul. Prusa 14, 08-110 Siedlce, tel. (25) 643 1256; e-mail: ehoroszewicz@wp.pl

2 Mgr Edyta Sweklej, Instytut Bioinżynierii i Hodowli Zwierząt, Uniwersytet Przyrodniczo-Humanistyczny w Siedlcach; e-mail: edi_007@poczta.onet.pl

3 Dr hab. Roman Niedziółka, prof. nadzw. UPH, Instytut Bioinżynierii i Hodowli Zwierząt, Uniwersytet Przyrodniczo-Humanistyczny w Siedlcach, e-mail: romann@uph.edu.pl

4 Dr hab. inż. Krzysztof Tereszkiewicz, Zakład Informatyki w Zarządzaniu, Politechnika Rzeszowska w Rzeszowie, Al. Powstańców Warszawy 8, $35-959$ Rzeszów, tel. (17) 86513 43; e-mail: kteresz@prz.edu.pl 
zorganizowany wypoczynek aktywności ruchowej z udziałem psich zaprzęgów ma swoje uzasadnienie w gospodarstwach agroturystycznych, szczególnie dla turystów posiadających własne psy.

Słowa kluczowe: agroturystyka, oferta wypoczynku, atrakcja turystyczna, aktywność, psie zaprzęgi.

\section{WSTĘP}

Światowe prognozy dotyczące ruchu turystycznego pokazują, że do roku 2020 przyjazdy turystów do Europy będą najwyżzze na świecie i wyniosą około $717 \mathrm{mln}$ osób. Tak więc Europa (głównie Unia Europejska) stała się najpopularniejszym kierunkiem turystycznym na świecie. W porównaniu do obecnej sytuacji liczba przyjazdów turystów do Europy jeszcze wzrośnie o około $200 \mathrm{mln}$ i w 2020 r. będzie stanowiła 45\% w turystycznym rynku globalnym ${ }^{5}$.

W dobie pogoni za karierą trudno się zrelaksować, nawet w czasie wolnym. Kolejne atrakcje turystyczne powszednieją i ludzie poszukują nowych, atrakcyjnych form spędzania czasu wolnego. Z badań Głównego Urzędu Statystycznego wynika, że w 2010 r. usługi agroturystyczne świadczyło blisko 5,8 tys. gospodarstw, które dysponowały ponad 51 tys. miejsc. Z danych Ministerstwa Rolnictwa i Rozwoju Wsi wynika, że w 2015 r. w Polsce było ponad 10 tys. gospodarstw agroturystycznych. W Polsce w $2013 \mathrm{r}$. funkcjonowało 45 stowarzyszeń agroturystycznych ${ }^{6}$. Stwarza to szansę nie tylko do odpoczynku, ale i trwałego przekierowania życia na spokojniejsze, związane z naturą tory. Łączenie turystyki aktywnej z przygodową wyzwala niezbędny poziom endorfin, co skutkuje doskonałym samopoczuciem. Prowadzenie usług agroturystycznych na atrakcyjnych turystycznie obszarach charakteryzuje się wysoką dochodowością, niezależnie od tego, czy jest ono głównym, czy dodatkowym źródłem dochodu w gospodarstwie. Właściciele podejmujący działalność agroturystyczną bardzo krótko czekają na zwrot inwestycji, szczególnie w gospodarstwach znajdujących się w rejonach o wysokich walorach przyrodniczych i kulturowych?

Należy podkreślić, że na świecie promocja turystyki aktywnej, w tym także agroturystyki jest słaba. Nawet wiodące kraje takie jak Włochy, Hiszpania, Francja wypoczynku agroturystycznego nie traktują priorytetowo (przynajmniej nie wszystkie regiony) w stosunku do innych intratnych biznesowo działów sektora turystyki. Lepiej ta sytuacja wygląda miedzy innymi w: Niemczech, Wielkiej Brytanii, Holandii, gdzie taka forma wypoczynku jest traktowana priorytetowo. Również w Polsce, aż 8 regionów jest priorytetowo zaangażowanych w promocję i marketing wypoczynku czynnego w ramach agroturystyki.

5 B. Walas, A. Cichońska, T. Buczek, D. Zientarska, M. Nalazek, K. Celuch, Marketingowa strategia Polski w sektorze turystyki na lata 2012-2020. Polska Organizacja Turystyczna, 2011, s. $1-215$.

6 C. Marcinkiewicz, Rozwój i stan polskiej agroturystyki, „Zeszyty Naukowe Wyższej Szkoły Humanitas. Zarządzanie", 2013, nr 1, s. 21-35.

7 K. Duczkowska-Małysz, Agroturystyka jako źródto alternatywnego zarobkowania $w$ rolnictwie [w:] L. Powichrowski, Gospodarstwo Agroturystyczne, MPiPS, 1998, s. 7-25: T. Nawrocki, Optacalność inwestycji $w$ gospodarstwach agroturystycznych położonych na terenie „Podlaskiego Przełomu Bugu, Zeszyty Naukowe AR we Wrocławiu, nr 540, Rolnictwo. LXXXVII, 2006, s. 361-365; W. J. Cynarski, J. Słupecki, Treści turystyki kulturowej w obszarze badań agroturystyki i turystyki wiejskiej w świetle polskiej literatury przedmiotu, Turystyka Kulturowa, 2011, s. 25-34. 
Wskazuje to na większą działalność pod względem promocji i marketingu agroturystyki w Polsce, niż na przykład na Węgrzech czy Słowacji - krajach bardziej postrzeganych jako turystyczne ${ }^{8}$.

Natomiast mieszkańcy miast i gmin turystycznych Podkarpacia najbardziej wskazywali, że charakter turystyczny podkreśla obecność naturalnego środowiska (czystość powietrza, czy wód) oraz walory kulturowe związane $\mathrm{z}$ danym miejscem. Dodatkowo istotnym czynnikiem wspierającym turystykę okazały się usługi turystyczne, a szczególnie: baza, informacja turystyczna i oznaczenie szlaków. Dla mieszkańców gmin o charakterze turystycznym ważne są walory kulturowe i krajobrazowe. Wpływ pozytywnego postrzegania miejsca o charakterze turystycznym był bardziej doceniany przez mężczyzn niż kobiety i dotyczyła sieci dróg, sieci kanalizacyjnej i wodociągowej oraz czystości powietrza ${ }^{9}$.

Wśród licznych atrakcji oferowanych przez właścicieli gospodarstw agroturystycznych na uwagę zasługują psie zaprzęgi, które mogą być przykładem turystyki aktywnej, przygodowej - pieszej i rowerowej, zimą zaś narciarskiej, mogą stać się także szlakiem questingowym ${ }^{10}$. Turystykę rowerową i jej odmianę w postaci 3- lub 4-kołowych wózków można odnaleźć w psich zaprzęgach. Coraz liczniej wytyczane szlaki turystyczne uatrakcyjniają ofertę gospodarstw agroturystycznych i mogą być bazą dla wypraw psim zaprzęgiem, który niewątpliwie zapewnia aktywny wypoczynek nie tylko rodzinie, ale także pupilom, na co dzień niedoświadczających tego typu atrakcji. Na ścianie wschodniej Polski, w obszarze województwa podlaskiego sklasyfikowano 70 szlaków turystycznych o łącznej długości 2653 km, z czego tylko w Puszczy Białowieskiej znajdują się 33 szlaki turystyczne i ścieżki edukacyjne, o długości 0,3-206 km, w woj. lubelskim zaś 56 szlaków o łącznej długości $2334,2 \mathrm{~km}^{11}$. Ze względu na to, że połowa społeczeństwa polskiego posiada psy, często „wakacyjny”, co zrobić z psem podczas urlopu można zmienić na wspólne spędzanie urlopu, aktywne zarówno dla właściciela, jak i pupila. Środowisko przyrodnicze ściany wschodniej charakteryzuje wysoki stopień lesistości - około 29,2\%, co sprzyja aktywnemu wypoczynkowi z psami ${ }^{12}$.

W ramach sportu zaprzęgowego obecnie występuje wiele dyscyplin, wśród których można wyróżnić nie tylko te klasycznie kojarzące się z sankami czy wózkami ciągniętymi przez psy, ale są to również: skijoring, pulka, bikejoring, canicross, rollpulka ${ }^{13}$.

Przykładem innowacyjnego produktu turystycznego utworzonego w oparciu na lokalnym dziedzictwie kulturowym i przyrodniczym jest questing. Jako forma zwiedzania i metoda $\mathrm{w}$ edukacji regionalnej został zastosowany po raz pierwszy w połowie lat dziewięćdziesiątych XX wieku w Stanach Zjednoczonych, w Polsce zaś na szerszą skalę został

8 B. Walas, A. Cichońska, T. Buczek, D. Zientarska, M. Nalazek, K. Celuch, Marketingowa strategia Polski...

9 K. Kud, M. Woźniak, Percepcja środowiskowych czynników jakości życia na obszarach wiejskich w województwie podkarpackim, „Humanities and Social Sciences”, 204, (2013), s. 63-74.

10 T. Nawrocki, Optacalność inwestycji...; M. Nowacki, Czym jest turystyka przygodowa? [w:] W. Siwiński, D.R. Tauber, E. Mucha-Szajek, Teoria i praktyka usług turystycznych, rekreacyjnych $i$ hotelarsko-żywieniowych w świetle badań, WSHiG, Poznań 2011, s. 281-290.

11 T. Nawrocki, Optacalność inwestycji...

12 E. Biernacka, Walory przyrodnicze Ściany Wschodniej Polski szansa rozwoju turystyki i rekreacji, „Zeszyty Naukowe Politechniki Białostockiej”, „Ekonomia i Zarządzanie”, 2009/14, s. 75-83.

13 M. Młocka, Startować można nawet z jamnikiem, ,Rzeczpospolita”, 2011, 8/9, http://www.rp.pl/artykul/699103.html?p=2; B. Tyrna, Długi spacer z psem, „Głos Ziemi Cieszyńskiej” 2008/40, s. 5. 
rozpowszechniony w 2011 roku. Szlaki questingowe, nazywane są questami (quest - ,poszukiwanie”, ,śledztwo”), to szlaki lub ścieżki tematyczne (w zależności od zajmowanej powierzchni). Charakterystycznymi cechami tego rodzaju szlaków jest określona tematyka (kulturowa, historyczna lub przyrodnicza), brak oznaczenia w terenie, możliwość samodzielnego zwiedzania według schematycznych map i wierszowanych wskazówek oraz rozwiązywanie zagadek w czasie przejścia trasą.

Questing stanowi połączenie metody zwiedzania, edukacji regionalnej, aktywnego wypoczynku oraz promocji dziedzictwa kulturowego i przyrodniczego. Metoda questingu łączy edukację regionalną z turystyką, rozrywkę ze zdobywaniem wiedzy i aktywnym spędzaniem czasu wolnego. Popularne określenie questingu to ,poszukiwanie skarbów”. W Polsce utworzono już około 250 szlaków questingowych. Sukcesywnie tworzona jest ogólnopolska sieć szlaków questingowych mająca objąć wszystkie województwa ${ }^{14}$. Motywy przewodnie i walory turystyczne, na których podstawie są tworzone szlaki questingowe są bardzo różnorodne. Niewykluczone jest utworzenie ścieżki tematycznej „Psie zaprzęgi”, którą można zaliczyć do Questu ,środki transportu”, zgodnie z podziałem questów według Clarka i Glazera ${ }^{15}$. Wymienione formy turystyczne można znaleźć w agroturystyce przy okazji rozszerzonej oferty gospodarstw oferujących dodatkowe atrakcje dla wczasowiczów zainteresowanych aktywnym spędzaniem czasu wolnego.

Celem badań była ocena aktualnej oferty aktywnych form spędzania wolnego czasu w gospodarstwach agroturystycznych w aspekcie jej wzbogacenia poprzez możliwości wypoczynku z psem.

\section{MATERIAŁ I METODY}

Materiał stanowiły wyniki ankiet przeprowadzonych w 2013 i 2014 roku wśród właścicieli losowo wybranych 120 gospodarstw agroturystycznych z terenu całego kraju. Zebrano informacje dotyczące oferowanych atrakcji turystycznych w analizowanych gospodarstwach takich jak kuligi, bryczki, kąpiele, wędkowanie, jazda konna, ognisko lub grill, spacery, zbieranie runa, uczestnictwo w pracach gospodarskich, gry zespołowe. Znalazło się pytanie dotyczące umożliwienia urlopowiczom aktywnego spędzenia czasu z psem - udział w psich zaprzęgach, przy opracowanej własnej ofercie lub korzystanie z usług firm zewnętrznych. Wśród zorganizowanych form oferty zaprzęgowej gospodarstw lub firm z nimi współpracujących znalazły się: treningi z psami zaprzęgowymi lub własnymi, nauka od podstaw ubierania i zaprzęgania psów, nauka poszczególnych komend i pracy na wózku czy saniach, przyzwyczajanie do zachowań w ekstremalnych sytuacjach, nauczanie umiejętnego czerpania radości z posiadania psa zaprzęgowego oraz ze sportu zaprzęgowego, przejażdżki na saniach lub w warunkach bezśnieżnych - na wózkach (w tym z możliwością samodzielnego powożenia), przygotowanie obozowiska, rozbicie namiotów, rozstawienie sprzętu, opowieści o rasach i historii zaprzęgów, szersza oferta (canicross, pulka, bikejoring, skijoring), kontakt z psami, fotografie, pokaz siły uciągu psów, projekcje filmów i slajdów, ognisko maszerskie.

14 A. Pawłowska, Questing jako innowacja w turystyce kulturowej, „Turystyka Kulturowa”, 2014/1, s. $30-46$.

15 D. Clark, S. Glazer, Questing. A Guide to Creating Community Treasure Hunts, Questing University Press of New England, Lebanon 2004, s. 17-27. 
Od właścicieli gospodarstw zebrano dane dotyczące kosztów uczestnictwa w poszczególnych imprezach związanych z psami.

Przeprowadzono jednocześnie ankiety wśród 100 osób w wieku 18-55 lat, zamieszkałych w miejscowościach liczących 10-500 tys. mieszkańców, zainteresowanych aktywnym spędzaniem wolnego czasu. Wszystkie badane osoby spędzały wcześniej urlop na wsi lub na łonie natury. W formularzu ankiety pytano o: spacery, wycieczki, jazdę konną, gry zespołowe, zbieranie runa leśnego, pływanie, przejażdżki bryczką, kulig, wędkowanie, ognisko, uczestnictwo w pracach gospodarskich. W drugiej części ankiety znalazły się pytania dotyczące psów: posiadanie psa a wybór miejsca urlopu, możliwość zabrania psa ze sobą na urlop a pozostawienie go w miejscu zamieszkania, u znajomych, rodziny czy w hotelu dla zwierząt. W tym celu ankietowani zostali zapytani o to, czy możliwość udziału w ofercie psich zaprzęgów skłoniłaby ich do wyboru na miejsce urlopu gospodarstwa agroturystycznego oferującego tę atrakcję, a także o wcześniejsze uczestniczenie w takich formach oferty gospodarstw agroturystycznych.

Wszystkie ankiety zostały zestawione w poszczególne grupy w celu dalszego ich omówienia $\mathrm{z}$ literaturą fachową.

\section{SPOSÓB SPEDZANIA WOLNEGO CZASU W GOSPODARSTWACH AGROTURYSTYCZNYCH}

Jak wynika z badań Zarębskiego ${ }^{16}$, w 2013 r. w gminach wiejskich znajdowało się $29,6 \%$ miejsc noclegowych, natomiast $w$ gminach miejsko-wiejskich $-22,1 \%$. W analizowanym roku na obszarach wiejskich (gminy wiejskie i miejsko-wiejskie) $57 \%$ miejsc noclegowych miało charakter całoroczny, przy czym w gminach miejskich udział miejsc noclegowych całorocznych wyniósł aż 80,6\%. Zróżnicowany charakter bazy noclegowej analizowanych gmin wpływa na liczbę udzielonych noclegów. W gminach wiejskich i miejsko-wiejskich w badanym roku, udzielono 38,5\% wszystkich noclegów w Polsce (dla porównania udział gmin miejskich wyniósł $61,5 \%$ ). Obszary wiejskie niezbyt licznie były odwiedzane przez turystów zagranicznych, którzy wykorzystali bazę noclegową na tym obszarze w $15,5 \%$.

Na podstawie przeprowadzonych badań ankietowych wśród 100 osób w wieku 18-55 lat (rys. 1), które mieszkały w miejscowościach liczących 10-500 tys. mieszkańców stwierdzono, że wszystkie osoby brały wcześniej udział w wypoczynku w gospodarstwie agroturystycznym. W badaniach uwzględniono wskazania na jedną lub więcej niż jedną formę spędzania wolnego czasu w gospodarstwie agroturystycznym. Osoby, które spędzały już wcześniej urlop na wsi lub na łonie natury, wskazały najbardziej preferowaną aktywność spędzania wolnego czasu w formie: spacerów (91\% osób), ognisko/grill (78\%), wycieczek (65\%). Ponad połowa respondentów w wyborze miejsca odpoczynki kierowała się dostępnością ośrodka do jeziora bądź stawu (57\%). W okresie zimowym chęć uczestnictwa w kuligu zgłosiło około $66 \%$ badanych.

Analiza odpowiedzi respondentów pokazała, że w obiektach agroturystycznych wolny czas chętnie spędzaliby oni, uprawiając różne formy ruchowe. Do takich należy zaliczyć chociażby jazdę konną czy wycieczki psich zaprzęgów. Zapytani o to, czy możliwość

\footnotetext{
${ }^{16}$ P. Zarębski, Wybrane elementy turystyki kulturowej jako czynnik rozwoju bazy noclegowej na obszarach wiejskich w Polsce, ,Turystyka Kulturowa”, 2015/1, s. 63-78.
} 
udziału w psich zaprzęgach skłoniłaby ich do wyboru danego gospodarstwa agroturystycznego oferującego tę atrakcję, aż $60 \%$ wszystkich odpowiedzi była twierdząca. Natomiast nikt $\mathrm{z}$ ankietowanych dotychczas nie zetknął się z podobną ofertą. $\mathrm{W}$ badanej grupie $59 \%$ posiadała psy, z czego $51 \%$ nie zamierza rozstawać się z pupilem podczas urlopu, dlatego możliwość zabrania pupila jest priorytetem przy wyborze miejsca noclegowego. Wśród badanych $49 \%$ z nich w czasie urlopu organizuje opiekę dla psa wśród znajomych lub w hotelach dla zwierząt, których nadal jest jeszcze niewiele, szczególnie w małych miejscowościach. Dlatego urlop połączony z aktywną formą i możliwością zabrania własnego pupila jest jedną z szans dla agroturystyki.

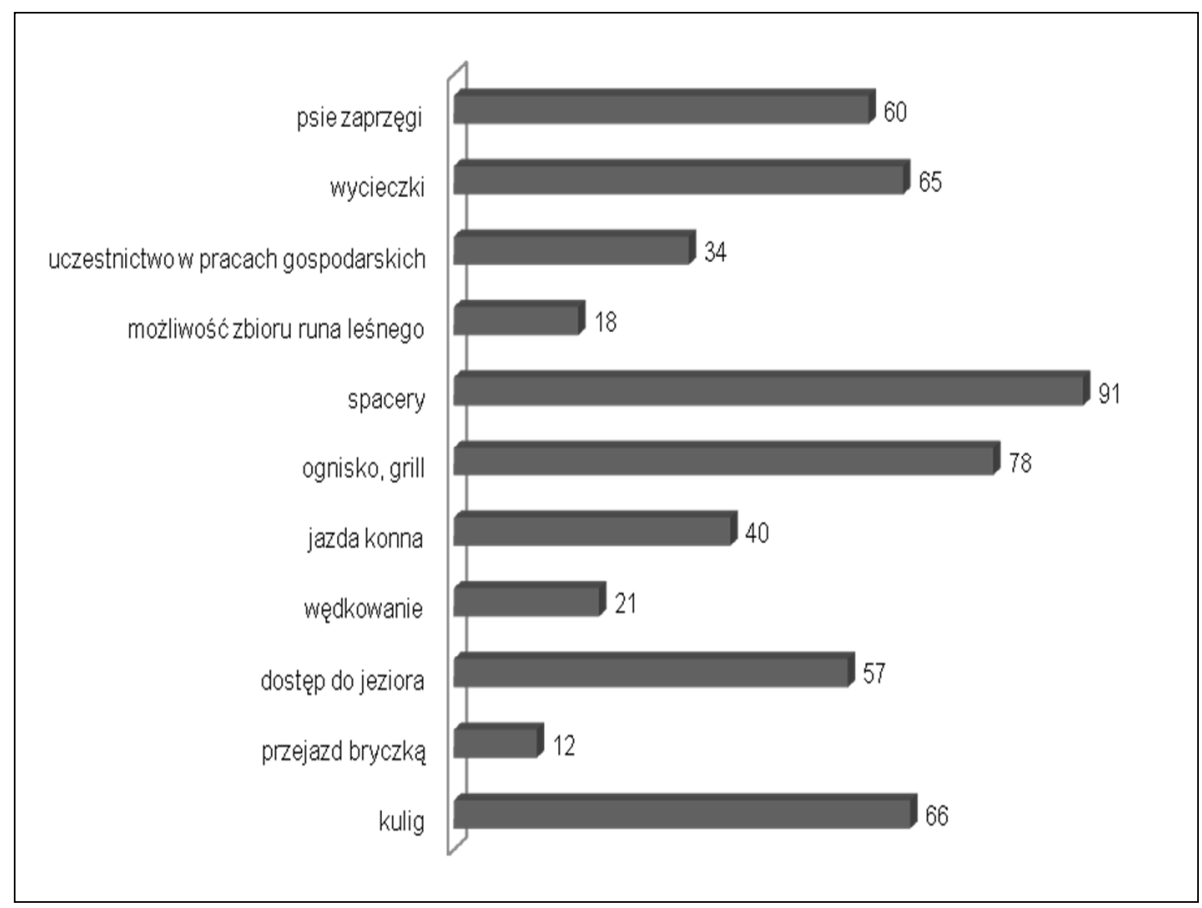

Rys. 1. Formy spędzania wolnego czasu preferowane przez turystów (\%)

Źródło: badania własne.

Najpowszechniej występującą ofertą (69\%) w gospodarstwach agroturystycznych było miejsce do gier zespołowych (boisko) jako sposób uatrakcyjnienia miejsca wypoczynku (rys. 2). Możliwość uczestnictwa w pracach gospodarskich (najczęściej przy obsłudze zwierząt w przydomowych mini ZOO - 45\%), możliwość korzystania z darów lasu deklarowało około 55\% badanych. Oferta miejsca do wspólnego ogniska czy grillowiska podobnie jak spacery były dość ważne dla agroturystów i stanowiły po 57\%. Natomiast możliwość aktywnego spędzenia czasu z psem oferowało jedynie 5\% gospodarstw, a tylko $2,5 \%$ z przebadanych proponowało udział w psich zaprzęgach. Tak więc gospodarstwa agroturystyczne nie miały rozwiniętej oferty w zakresie psich zaprzęgów, jakiej oczekują turyści. Dlatego należałoby do tych gospodarstw wprowadzić zwierzęta podnoszące atrakcyjność miejsca - 
niewątpliwie należą do nich psy, ale również konie i inne małe zwierzęta. W bardziej korzystnej sytuacji są gospodarstwa agroturystyczne oferujące jazdę konną (40\%) czy przejażdżki bryczką (20\%), ponieważ badani chętniej wybierali gospodarstwa z taką ofertą na urlop (często krótki, trwający tydzień) lub weekendowy odpoczynek. W dobrze zorganizowanych ośrodkach agroturystycznych z końmi wiązało się to z cyklicznymi przyjazdami.

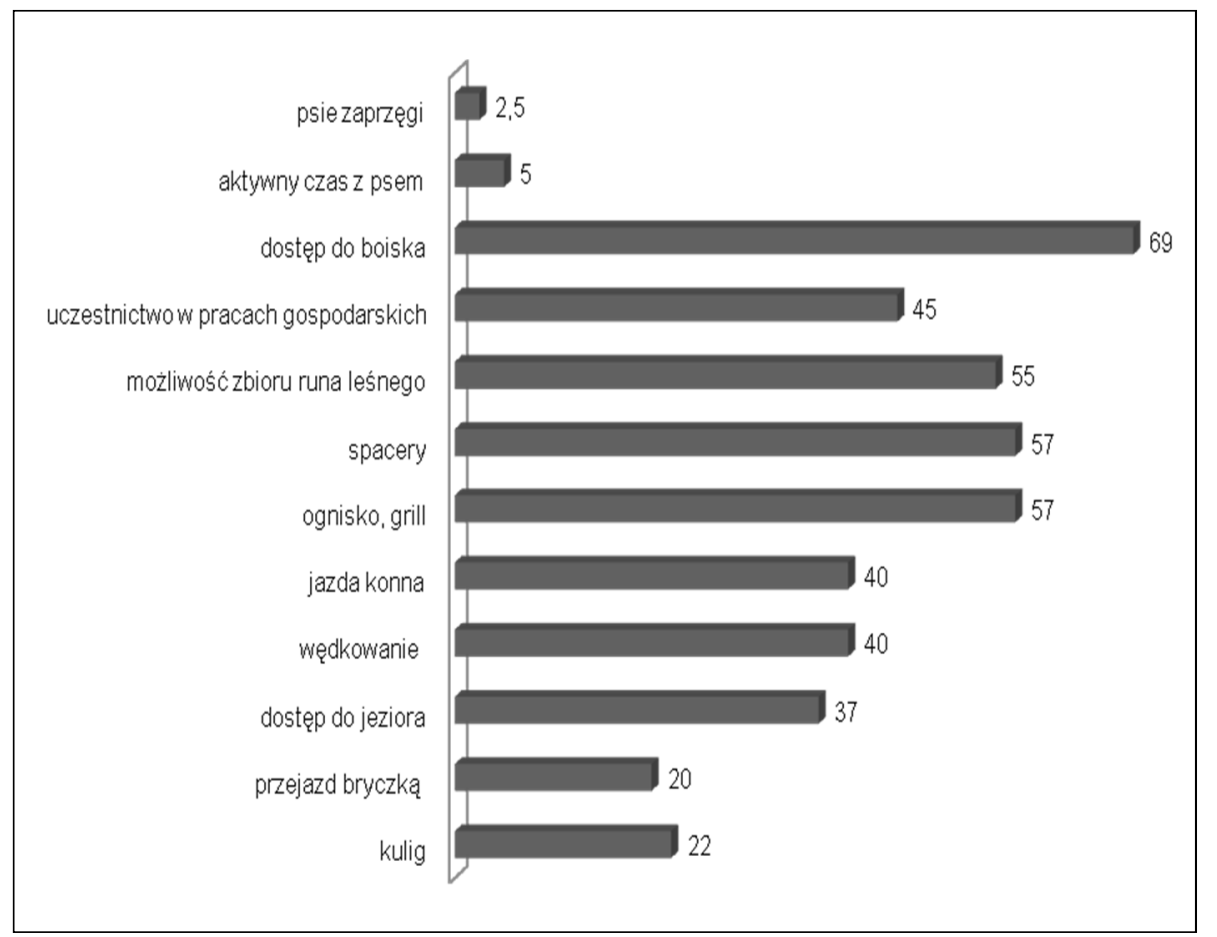

Rys. 2. Oferowane atrakcje gospodarstw agroturystycznych

Źródło: badania własne.

Ponadto osoby korzystające obecnie z agroturystyki nie preferują na przykład możliwości zbioru runa leśnego, czy uczestnictwa w pracach gospodarskich. Z takich form mogli korzystać powszechnie na miejscu wypoczynku, blisko połowa gospodarstw agroturystycznych, bowiem miała je w ofercie. Świadczy to o zmieniających się nawykach i podejściu do aktywnej formy wypoczynku na wsi.

Oferty rekreacyjne gospodarstw agroturystycznych ograniczały się głównie do organizowania polowań, kąpielisk, wędkarstwa, jazdy konnej czy uczestniczenia w pracach gospodarskich ${ }^{17}$. Takie atrakcje przestają być w pełni satysfakcjonujące. Poszukuje się nowych form spędzania wolnego czasu. Jednym ze sposobów uatrakcyjnienia działalności gospodarstw agroturystycznych jest chów zwierząt, na przykład koni. Możliwość jazdy

${ }^{17}$ E. Niczyporuk, Stan i możliwości rozwoju wybranych gospodarstw agroturystycznych Podlasia, praca magisterska, AWF w Warszawie, IWFiS w Białej Podlaskiej, Biała Podlaska 1999. 
konnej to jedna z najczęściej spotykanych atrakcji oferowanych turystom przez właścicieli gospodarstw agroturystycznych. Obecność koni jest czynnikiem przyciągającym turystów do gospodarstwa ${ }^{18}$.

W gospodarstwach agroturystycznych z powiatu siedleckiego najczęściej oferowana atrakcją była jazda konno i przejażdżka bryczką. Stanowiły one odpowiednio 21-32\% w zależności od gospodarstwa. Na drugim miejscu były rowery, ale tylko $11 \%$ turystów korzystało z takiej formy ruchowej. W tych gospodarstwach nie oferowano żadnych imprez ruchowych z udziałem psów, mimo że turyści zgłaszali zapotrzebowanie na rozszerzenie oferty ruchowej ${ }^{19}$.

\section{PSIE ZAPRZEGI JAKO OFERTA SPECDZANIA WOLNEGO CZASU W GOSPODARSTWACH AGROTURYSTYCZNYCH}

Grupa 33\% spośród ankietowanych gospodarstw agroturystycznych dysponowała własną ofertą, a $67 \%$ współpracowało z organizacjami zajmującymi się prowadzeniem kursów i popularyzacją psich sportów między innymi psich zaprzęgów. Najbardziej rozpowszechnione formy oferty z udziałem psów to: kontakt z psem, przejażdżki, nauka komend i trening z psami (rys. 3).

W tych wypadkach gospodarstwo oferowało tylko jedną zorganizowaną ofertę dla turysty, która wypełniała cały czas aktywności ruchowej. Wśród zorganizowanych form oferty zaprzęgowej gospodarstw lub firm z nimi współpracujących znalazły się: treningi z psami zaprzęgowymi lub własnymi psami (100\%), nauka od podstaw ubierania i zaprzęgania psów (67\%), nauka poszczególnych komend i pracy na wózku czy saniach (100\%). Natomiast rzadziej przekazywano turystom możliwość przyzwyczajania się do zachowań z psem w ekstremalnych sytuacjach (33\%), nauczanie umiejętnego czerpania radości z posiadania psa zaprzęgowego oraz ze sportu zaprzęgowego (33\%). Wśród turystów zaobserwowano wciąż wysoki odsetek chętnych do przejażdżki na saniach lub w warunkach bezśnieżnych - na wózkach (100\%, w tym $67 \%$ z możliwością samodzielnego powożenia).

W tych wypadkach wymaga to zaangażowania osób fachowo wyszkolonych, z umiejętnościami praktycznej nauki obchodzenia się z psem w różnych sytuacjach dlatego jest jeszcze niewielka grupa gospodarstw, które takie formy realizują. Mimo że są one bardzo atrakcyjne dla turystów, szczególnie z własnymi psami, czasami może być problem ze zgromadzeniem odpowiedniej grupy chętnych.

Inne formy zajęć, takie jak przygotowanie obozowiska, rozbicie namiotów, rozstawienie sprzętu, stanowiły w gospodarstwie tylko $1 / 3$ aktywnego czasu, a zajęciom tym często towarzyszyły opowieści o rasach i historii zaprzęgów i na przykład pokazy siły uciągu psów.

Zawody psów jucznych stają się coraz popularniejsze dzięki wzrastającemu zainteresowaniu rekreacją na łonie natury i pieszymi wędrówkami. Juki składają się z dwóch toreb połączonych taśmą przełożoną przez grzbiet psa. Treningowo zakłada się zwierzęciu puste

18 J.L. Sokół, J. Boruch, Ekologizacja gospodarstw agroturystycznych w powiecie białostockim, „Kwartalnik Wydziału Zarządzania, Ekonomia i Zarządzanie”, 3/1, (2011), s. 95-112.

19 T. Nowogródzka, K. Pieniak-Lendzion, Propozycje ofert gospodarstw agroturystycznych, a oczekiwania konsumentów, „Zeszyty Naukowe UPH w Siedlcach. Administracja i Zarządzanie”, 100/27, (2014), s. 97-108. 


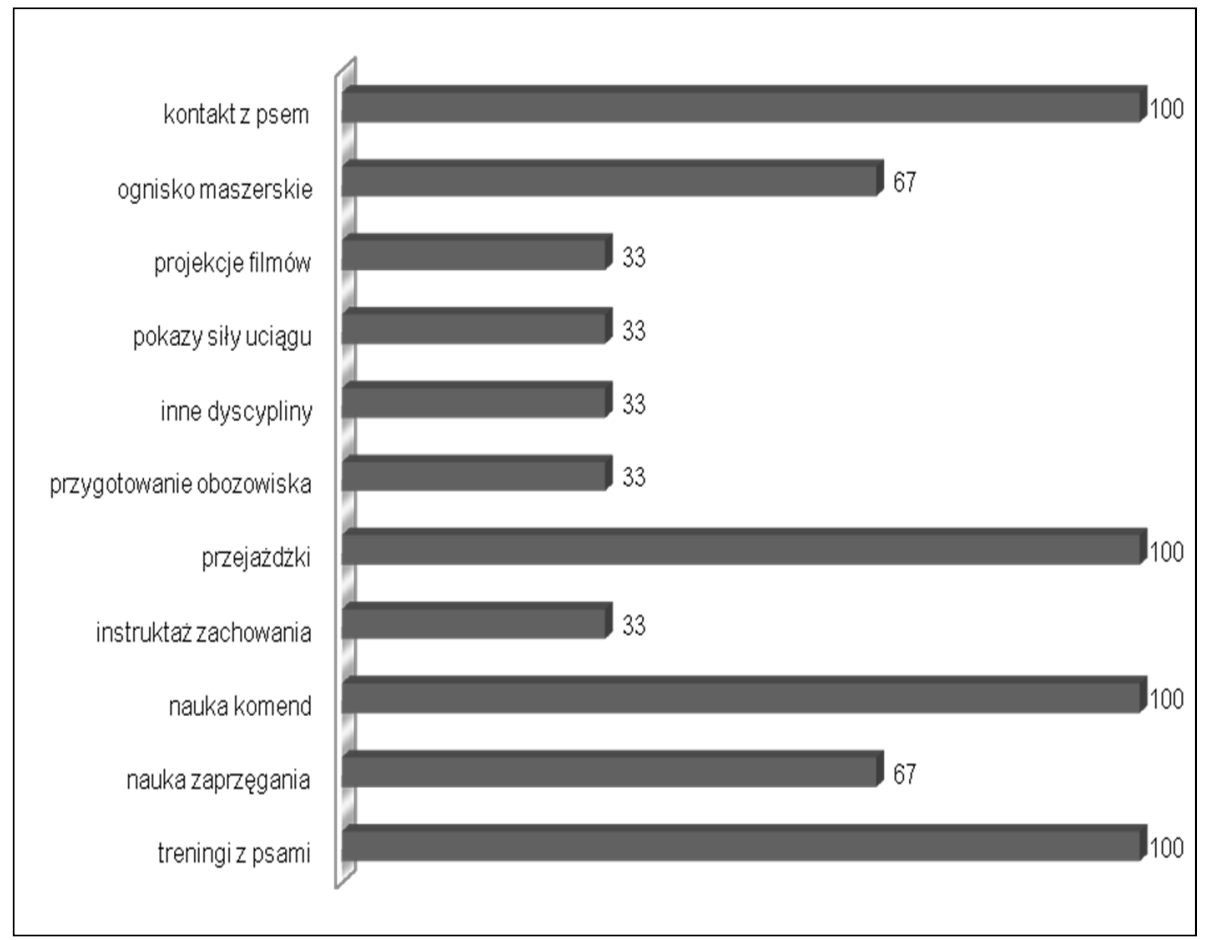

Rys. 3. Oferta psich zaprzęgów w analizowanych gospodarstwach agroturystycznych Źródło: opracowanie własne.

juki, następnie stopniowo zwiększa się ich ciężar oraz dystans wędrówki. Docelowo praktykuje się obciążanie psa bagażem o wadze równej 1/3 masy ciała psa, równo rozłożonym w obu jukach. Wśród typowych psów zaprzęgowych, takich, którym wysiłek sprawia szczególnie dużo radości i które same potrafią kontrolować zmęczenie, można wymienić: alaskan malamute, syberian husky, samojeda ${ }^{20}$.

W literaturze wymieniane są również inne rodzaje aktywności z psem, między innymi maratony (temperatura nie może przekraczać wówczas $15^{\circ} \mathrm{C}$, ponieważ wysiłek w wyższej temperaturze może być niebezpieczny dla psów), triathlony, skutery (podobnie jak w bikejoringu pies ciągnie nieco zmodyfikowany skuter, z dospawanym uchwytem, wzmocnionymi progami, na których można stanąć), survival z psami, rakiety śniegowe, łyżwy ${ }^{21}$.

Szersza oferta w analizowanych gospodarstwach była wypełniona ciekawymi formami wykorzystania psów zaprzęgowych (canicross, pulka, bikejoring, skikjoring) - wyniosła $33 \%$. Te zajęcia często łączono $\mathrm{z}$ pokazem siły uciągu psów - oferta 1/3 gospodarstw. W ostatnim czasie coraz częściej gospodarstwa (2/3 czasu oferty ruchowej) oferują ogniska maszerskie, które w ciekawy sposób łączą środowisko kynologiczne z turystami w okresie urlopu.

${ }^{20}$ M. Szmurło, I. Szmurło, Husky i inne. Sport psich zaprzęów, Warszawa 2002.

${ }^{21}$ A. Wieczorek, Husky syberyjski, Łódź 2005. 
Wypoczynek w gospodarstwie agroturystycznym z ofertą zajęć z psami pod okiem opiekuna może być ciekawie spędzonym czasem, tym bardziej, gdy turysta zdobędzie fachową i praktyczną wiedzę. Osoby uczestniczące odpłatnie w takich zajęciach chętnie brały w nich udział szczególnie z własnymi psami.

Tabela 1. Średnie ceny za poszczególne usługi oferty zaprzęgowej w analizowanych gospodarstwach agroturystycznych

\begin{tabular}{|l|c|c|}
\hline \multicolumn{1}{|c|}{ Forma oferty zaprzęgowej } & Średnia cena & $\begin{array}{c}\text { Przedział cenowy } \\
\text { (min.-maks.) }\end{array}$ \\
\hline $\begin{array}{l}\text { Kontakt z psem } \\
\text { (zł/godz.) }\end{array}$ & 40 & $30-55$ \\
\hline $\begin{array}{l}\text { Ognisko maszerskie + wyżywienie } \\
\text { (zł/os./grupa) }\end{array}$ & 65 & $50-90$ \\
\hline $\begin{array}{l}\text { Projekcje filmów } \\
\text { (zł/os./grupa) }\end{array}$ & 12 & $10-15$ \\
\hline $\begin{array}{l}\text { Pokazy siły uciągu } \\
\text { (zł/os./grupa) }\end{array}$ & 30 & $25-35$ \\
\hline $\begin{array}{l}\text { Inne dyscypliny } \\
\text { (zł/godz.) }\end{array}$ & 35 & $25-50$ \\
\hline $\begin{array}{l}\text { Przygotowanie obozowiska } \\
\text { (zł/os.) }\end{array}$ & 23 & $20-30$ \\
\hline $\begin{array}{l}\text { Przejażdżki } \\
\text { (zł/os./grupa) }\end{array}$ & 50 & $35-250$ \\
\hline $\begin{array}{l}\text { Instruktarz zachowania indywidualnie } \\
\text { (zł/godz.) }\end{array}$ & 40 & $35-70$ \\
\hline $\begin{array}{l}\text { Nauka komend indywidualnie } \\
\text { (zł/godz.) }\end{array}$ & 50 & $40-80$ \\
\hline $\begin{array}{l}\text { Nauka zaprzęgania indywidualnie } \\
\text { (zł/os.) }\end{array}$ & 55 & $15-30$ \\
\hline $\begin{array}{l}\text { Treningi z psami indywidualnie } \\
\text { (zł/godz.) }\end{array}$ & 20 & $40-100$ \\
\hline
\end{tabular}

Źródło: opracowanie własne; ceny zależą od wielkości grup i dystansu.

W tabeli 1 przedstawione zostały średnie ceny poszczególnych usług z udziałem psich zaprzęgów i mają one charakter informacyjny dla zainteresowanych gości. Ceny uczestnictwa w imprezach zaprzęgowych kształtują się na poziomie $65 \mathrm{zł} /$ osobę przy grupie liczącej 35 osób. Ceny przejażdżek psimi zaprzęgami zależą głównie od dystansu i kształtują się na poziomie 35-250 zł. Średnia cena takich usług to koszt 50 zł/osobę i jest on wyższy w wypadku mało licznej grupy. Natomiast dłuższe wyprawy to wydatek od 120 zł od osoby za godzinę. Zainteresowaniem turystów cieszyła się forma odpłatnego szkolenia psów pod okiem trenera. Średni koszt kształtował się w gospodarstwach na poziomie 55 zł za godzinę z maksymalną ceną nawet 100 zł za godzinę indywidualnej lekcji. Należy podkreślić, że koszt znacznie wzrastał w wypadku opłacania trenera przez gospodarzy. Podobną zależność obserwowano w wypadku nauki komend czy instruktażu zachowania z psem w różnych sytuacjach.

\section{PODSUMOWANIE}

W ostatnich latach także w naszym kraju obserwujemy ciągły rozwój agroturystyki, czego dowodem jest stale przybywająca liczba miejsc świadczących całoroczne usługi 
agroturystyczne. Z tej formy w naszym kraju korzysta już ponad 38 \% naszych rodaków i 15\% gości z zagranicy. Istotnym atutem agroturystyki jest możliwość aktywnego spędzania urlopu, co na dużą skalę obserwujemy już w Niemczech, Wielkiej Brytanii czy Holandii. Wśród atrakcji turystyki aktywnej na uwagę zasługują psie zaprzęgi realizowane na szlakach turystycznych typu questing o interesujących walorach krajobrazowych i edukacyjnych. Możliwość posiadania w ofercie psich zaprzęgów skłoniłaby turystów do wyboru danego gospodarstwa agroturystycznego, co pokazują badania własne. Jednak gospodarstwa agroturystyczne oferowały gry zespołowe jako forma aktywności ruchowej. Natomiast aktywne spędzanie czasu z psem miało tylko 5\%, w tym psie zaprzęgi 2,5\% gospodarstw. $\mathrm{W}$ analizowanych gospodarstwach oferujących psie zaprzęgi duże uznanie wśród gości posiadających własne psy były treningi z psami zaprzęgowymi, nauka komend i pracy na wózku lub na saniach. Jednak ta forma aktywności wymagała często od właścicieli gospodarstw korzystania z firm zewnętrznych, aby spełnić oczekiwania turystów. Dlatego proponowane odpłatne szkolenia psów pod okiem trenera były akceptowane przez gości i wychodziły naprzeciw ich zainteresowaniom.

\section{LITERATURA}

[1] Biernacka E., Walory przyrodnicze Ściany Wschodniej Polski szansa rozwoju turystyki i rekreacji, „Zeszyty Naukowe Politechniki Białostockiej Ekonomia i Zarządzanie” 2009/14, s. $75-83$.

[2] Clark D., Glazer S., Questing. A., Guide to Creating Community Treasure Hunts, Questing University Press of New England, Lebanon 2004, s. 17-27.

[3] Cynarski W.J., Słupecki J., Treści turystyki kulturowej w obszarze badań agroturystyki i turystyki wiejskiej w świetle polskiej literatury, ,Turystyka Kulturowa” 2011, s. 25-34.

[4] Duczkowska-Małysz K., Agroturystyka jako źródto alternatywnego zarobkowania w rolnictwie [w:] L. Powichrowski, Gospodarstwo agroturystyczne, „MPiPS” 1998, s. 7-25.

[5] Kud K., Woźniak M., Percepcja środowiskowych czynników jakości życia na obszarach wiejskich w województwie podkarpackim, „Humanities and Social Sciences” 20/4 (2013), s. 63-74.

[6] Marcinkiewicz C., Rozwój i stan polskiej agroturystyki, ,Zeszyty Naukowe Wyższej Szkoły Humanitas w Sosnowcu. Zarządzanie" 14/1, (2013), s. 21-35.

[7] Młocka M., Startować można nawet z jamnikiem, „Rzeczpospolita” 2011/8/9, http://www.rp.pl/artykul/699103.html?p=2.

[8] Nawrocki T., Opłacalność inwestycji w gospodarstwach agroturystycznych położonych na terenie „Podlaskiego Przetomu Bugu”, ,Zeszyty Naukowe Akademii Rolniczej we Wrocławiu, Rolnictwo" 2006/540, s. 361-365.

[9] Niczyporuk E., Stan i możliwości rozwoju wybranych gospodarstw agroturystycznych Podlasia, praca magisterska, AWF w Warszawie, IWFiS w Białej Podlaskiej, Biała Podlaska 1999.

[10] Nowacki M., Czym jest turystyka przygodowa? [w:] W. Siwiński, D.R. Tauber, E. MuchaSzajek, Teoria i praktyka ustug turystycznych, rekreacyjnych $i$ hotelarsko-żywieniowych $w$ świetle badań, WSHiG, Poznań 2011, s. 281-290.

[11] Nowogródzka T., Pieniak-Lendzion K., Propozycje ofert gospodarstw agroturystycznych a oczekiwania konsumentów, ,Zeszyty Naukowe UPH w Siedlcach, Administracja i Zarządzanie", 100/27, (2014), s. 97-108. 
[12] Pawłowska A., Questing jako innowacja w turystyce kulturowej, „Turystyka Kulturowa” 2014/1, s. 30-46.

[13] Sokół J.L., Boruch J., Ekologizacja gospodarstw agroturystycznych w powiecie białostockim, „Kwartalnik Wydziału Zarządzania. Ekonomia i Zarządzanie” 3/1 (2011), s. 95-112.

[14] Szmurło M., Szmurło I., Husky i inne. Sport psich zaprzegów, Agencja Wydawnicza Egros, Warszawa 2002.

[15] Tyrna B., Długi spacer z psem, „Głos Ziemi Cieszyńskiej” 2008/40, s. 5.

[16] Walas B., Cichońska A., Buczek T., Zientarska D., Nalazek M., Celuch K., Marketingowa strategia Polski w sektorze turystyki na lata 2012-2020, „Polska Organizacja Turystyczna” 2011, s. 1-215.

[17] Wieczorek A., Husky syberyjski, „Galaktyka”, Łódź 2005.

[18] Zarębski P., Wybrane elementy turystyki kulturowej jako czynnik rozwoju bazy noclegowej na obszarach wiejskich $w$ Polsce, ,Turystyka Kulturowa” 2015/1, s. 63-78.

\section{DOGS AS A FORM OF ENRICHMENT AGROTURISTIC FARMS OFFER}

Agrotourism is frequently appreciated form of spending the leisure time, which is indicated by increase of the number of touristic farms. Change of the trend of rest from passive into active is observed and participation in sled dog racing can be an example for it. Competent connection of cultural education and the active leisure is also a good example of touristic form which is questing, where participation of dogs is also desired. In Poland there is noticed intensive increase of the number of questing trails, which exceeds 250 . Offers of active forms of spending the free time in tourist farm in the aspect of enhancing them in possibilities of rest with the dog were studied. The research is based on survey conducted amongst owners of touristic farms from the area of Poland. Moreover persons interested in active spending the leisure time in the village or in the bosom of nature were investigated. Survey revealed that for these tourists walks and a campfire were the most active forms of spending summer time, and in the winter period sleigh ride was preferred. Spending the free time with the participation of sled dog teams constituted the $60 \%$ of surveyed. It is worth noticing that $59 \%$ of tourists possesses dogs and $51 \%$ declares the willing of spending vacation with them. The most universal offer of agrotouristic farms was an access to the playground (69\%); dog racing appeared only in the $2.5 \%$ of farms offers. Trainings with sled dogs, learning of commands and the work on the cart or the sledge appeared the most numerous offer of dog racing. Displays of behaviours of dogs in extreme conditions were the least numerous offers, because farms owners have often been obliged to use services of qualified external persons, however a paid form of training dogs under the coach control, learning of commands and instructions of leading the dog in different situations, have been popular. The study revealed that professionally organised rest of the physical activity with the participation of sled dogs had its grounds in agrotourism, above all for tourists having own dogs.

Keywords: agrotourism, offer recreation, tourist attraction, activity, sledge dogs.

DOI:10.7862/rz.2017.hss.24

Przestano do redakcji: luty $2017 \mathrm{r}$. Przyjęto do druku: czerwiec 2017 r. 